\title{
Sex-Based Discrimination in the Mental Institutionalization of Women
}

\author{
Robert T. Roth* \\ Judith Lerner**
}

And out of the ground the Lord God formed every beast of the field, and every fowl of the air; and brought them unto Adam to see what he would call them: and whatsoever Adam called every living creature, that was the name thereof.

And Adam gave names to all cattle, and to the fowl of the air, and to every beast of the field; but for Adam there was not found an help meet for him.

And the Lord God caused a deep sleep to fall upon Adam, and he slept: and He took one of his ribs, and closed up the flesh thereof;

And the rib, which the Lord God had taken from man, made He a woman. . . .

And Adam said, This is now bone of my bones, and flesh of my flesh: she shall be called Woman . . . .

Genesis 2:19-23

Ever since the time of Adam, giving names to things has been a principal means of controlling them. In naming his fellow creatures, mcluding wolnan, Adam was asserting and exercising his dominion over them. This article will consider another naming process, the business of labelling woinen under the various categories of "mental illness." 1 This process, too, involves the assertion of authority and control, of a kind and degree warranting closer judicial scrutiny than it has so far received. ${ }^{2}$

* Director, Center for the Study of Legal Authority and Mental Patient Status, Inc. (LAMP), Berkeley, California; B.A. Fordham University, 1968; J.D. Yale University, 1971.

*: B.A. Brooklyn College, 1968; J.D. Hastings College of the Law, 1974.

1. This criticism of psychiatry is by no means intended to denigrate the enterprise of conceptualizing, systematizing, and expanding available knowledge concerning the human unind. The psychological theorist and clinical practitioner attempt difficult and important functions in probing the nature of human personality, and in working to ease the pain of many people whose difficulties in living have no readily apparent resolution. The objection is directed rather to the exaggerated sense our culture has developed of the expertise possessed by this group, and to the legal power which has been invested in them as a result.

2. Constitutional criticism of the commitment process thus far has been concerned primarily with procedural due process questions such as notice, right to counsel, burden of proof, and so forth. E.g., Lessard v. Schmidt, 349 F. Supp. 1078 (E.D. Wis. 
The story of Eden also illustrates the way a parable can reinforce beliefs about political and social power. As this particular story would liave it, woman was created as an adjunct and companion to man. Perhaps this story originated in part simply as an attempt to explain the existence of two sexes in the human species. But in offering an explanation based upon an implicit theory of male priority, the parable becanie more than just a story; it became an imstrument of the system of ideas that it implicitly affirms. Similarly, the myth of mental illness ${ }^{3}$ acts not purely as a descriptive or scientific system of ideas, but as a justification for the subordinate social status of women. ${ }^{4}$ Psy-

1972), vacated, 94 S. Ct. 713 (1974). Recent criticism, however, goes to substantive due process questions as well. E.g., Ferleger, Loosing the Chains: In-Hospital Civil Liberties of Mental Patients, 13 Santa Clara LAw. 447 (1973); Roth, Dayley \& Lerner, Into the Abyss: Psychiatric Reliability and Emergency Commitment Statutes, 13 SANTA Clara Law. 400 (1973) [hereinafter cited as Roth, et al.]. Recent litigation has dealt with the implications of the constitutional guarantees of privacy and freedom of expression for involuntary institutional situations. E.g., Kaimowitz v. Mich. Dep't of Mental Health, Civ. No. 73-19434-AW (Wayne County, Mich., Cir. Ct., July 10, 1973), 5 Clearinghouse Rev. 302-03 (September 1973). The emerging "right to treatment" has also attracted the attention of a number of courts, e.g., Wyatt v. Stickney, 344 F. Supp. 373, 344 F. Supp. 387 (M.D. Ala. 1972), as well as commentators, e.g., Schwitzgebel, Right to Treatment for the Mentaliy Disabled: The Need for Realistic Standards and Objective Criteria, 8 HaRv. Crv. Rights-Civ. LiB. L. Rev. 513 (1973); Note, Constitutional Law: Mental Patients and Court Ordered Standards of Treatment (Wyatt v. Stickney, M.D. Alabama 1972), 25 U. FLA. L. Rev. 614 (1973). The notion of a "right" to receive involuntary treatment would appear to be somewhat incongruous, but the more logical formulation, of a right to refuse trentment, has been little explored. See Garfield \& Waitskin, The Right to Treatment and the Right to Refuse Treatment (1973) (unpublished paper on file with the Center for the Study of Legal Authority and Mental Patient Status, P.O. Box 822, Berkeley, Califoruia 94701).

3. The expression "myth of mental illness" is a shorthand reference to the fact that, apart from the relatively rare cases of organic impairment, there is no convincing evidence that behaviors labeled as "symptoms of mental illness" are in fact medical problems. Absent any genuinely scientific or objective definition, the term "mental illness" comes to be applied in ways which have socio-political implications. For a comprehensive criticism of the theory of mental illness on scientific-methodological grounds, see T. SZASZ, The MYTH of MENTAL IlLNESs 1-110 (1961) [hereinafter cited as MYth of Mental IllNess]. T. Szasz, The MaNufacture of Madness (1970) [heremafter cited as MANUFACTURE OF MADNESS], develops a socio-historical perspective on the myth. Dr. Thomas Scheff presents his own formulation of the inadequacies of current psychological theories of mental illness and develops a sociological reformulation in T. Scheff, Being Mentally Ill 55-101 (1966) [heremafter cited as ScHefF]. A number of criticisms are summarized in A. Rogow, THE PSYchiatrists 21-30 (1970) [hereinafter cited as Rogow].

4. See notes 18-22 Infra and accompanying text. Our society has to a grcat extent treated women as consigned by their anatomy to a restricted range of social roles. See generally Sail'er Inn, Inc. v. Kirby, 5 Cal. 3d 1, 485 P.2d 529, 95 Cal. Rptr. 329 (1971); G. MYrdal, AN AMERICAN DILEMma, Appendix $V$ (1944); Hacker, Women as a Minority Group, 30 Social Forces 60 (1951) [hereinafter cited as Hacker]; Seidenberg, The Submissive Majority, 55 CoRNell L. Rev. 262 (1970).

The belief that women are inferior to men substantially predates the founding of this country, and was brought here with the common law. A. ADLER, UNDERSTANDINo 
chiatry, of course, has no monopoly on the belief in a rigidly defined female role; it appears, rather, to derive this belief from its historical and social context. It serves to justify the retention and application of that belief by society and the law. ${ }^{5}$

Nor are women the only persons against whom the accusation of mental illness is applied in discrimmatory fashion. A broader consideration of the process of diagnosis and commitment would reveal that the dynamics of power and status operate in general ways against all persons accused of mental illness. In particular such discrimination could be productively studied according to such additional factors as race, ${ }^{6}$ age, ${ }^{7}$ and economic class. ${ }^{8}$

But because discrimination against women appears to be one of the most widespread yet least recognized varieties, it is especially critical that attorneys who become involved in representing female clients at commitment and release proceedings be watchful to detect and challenge abuses whenever they arise. Accordingly, a final focus of this article is an effort to inform attorneys and judges of the ways in which it may be possible to penetrate a seemingly incontrovertible medical diagnosis to reveal the underlying basis in norm and prejudice. The article concludes by offering a series of interim proposals that defense attorneys and courts may use to decrease the impact of sex-based discrimination until more thoroughgoing and permanent reform can be effected.

HUMaN NATURE 129-30 (W. Wolfe transl. 1927) [hereinafter cited as ADLER]; L. Kanowitz, Women aNd the LAW: The UNFinished Revolution (1969) [hereinafter cited as KaNowrtz]; Mead \& Stern, Woman, Position in Society, in 15 Encyclopedia OF THE SOCIAI SCIENCEs 439 (1937). The idea apparently retains a good deal of vitality in American society, as well as in the legislative and judicial mind. KANOwITZ, supra at 41-55. For a discussion of legislative characterizations of the proper status of woinen, see id. at 171 .

This Article is not intended to affirm psychiatric definitions of the male role, which, while accorded superior social status, is also himited as presently defined.

5. Instead of challenging this belief, psychiatry has served to give it the aura of scientific truth. "The writings and teachings of psychiatry have helped to provide a rationale for keeping woinen in a subservient position." S. Halleck, THE Politics of Therapy 125 (1972) [hereinafter cited as Halleck]. See also K. Millett, SeXual Politics 241 (1971) [hereinafter cited as MILLETr].

6. E.g., S. Sillen \& A. THOMAS, RACisM AND Psychiatry (1970).

7. HaLleCK, supra note 5, at 112-14. See also M. LOWENTHAI, LIVES IN Distress: The Paths of the EIDeriy to the Psychiatric Ward (1964); National INstitute of Mental Health, Mental Health Statistics, Analytical \& Spectal Study Reports, Series B, No. 5, The Mental Health System-1971 at 28 (1973).

8. A. Hollingshead \& F. Redlich, Social Class and MeNtal Iliness: A Community Study 339-41 (1958); J. Myers, L. BeAN \& M. Pepper, A Decade Later: A Follow-up of Social Class and Mental Illness (1968); Brill \& Starrow, Social Class and Psychiatric Treatment, in Mental Health of THE POOR 74 (F. Riessman, J. Cohen \& A. Pearl eds. 1964); Weihofen, Mental Health Services for the Poor, 54 Calif. L. Rev. 920 (1966). 


\section{SeX-Based Discrimination In Psychiatric Theory}

Research reveals that women are often diagnosed as mentally healthy or mentally ill on the basis of a different standard from that used for men. ${ }^{9}$ This standard is more restrictive in the range of behavior considered normal and has the effect of confirming and reinforcing the subordinate social status of women. ${ }^{10}$ One recurring source of this differential standard is the psychiatric belief that wounan's anatomy dictates her destiny. ${ }^{11}$ Freud, for example, believed that women unconsciously saw themselves as mutilated males,

9. Of course, one cannot speak of "psychiatric standards" or "psychiatric theory" as though these were unitary and agreed upon concepts. There are, however, a number of concepts which to some extent unify and underlie the literaturc of psychiatry and clinical psychology. See Ennis \& Litwack, Psychiatry and the Presumption of Expertise: Flipping Coins in the Courtroom, 62 CallF. L. REv. 693 (1974) (this issuc). As in any field, there are leading theoreticians, and some theories are more fashionable than others. But, intradisciplinary distinctions and conflicts notwithstanding, the general body of psychiatric literature has at least the consistency of a persistent anti-feinale bias. P. CHESLER, WOMEN AND MADNESS 75-133 (1972) [hereinafter cited as CHESLER]; HALlECK, supra note 5, at 123-27; MILLETT, supra note 5, at 239-312; Gelb, Masculinity-Femininty-A Study in Imposed Inequality, in PsychonNalysis aND WOMEN 363, 365-68 (J. Miller ed. 1973); Horney, Flight from Womanhood, in id. at 5; Seidenberg, Is Anatomy Destiny?, in id. at 306, 308; Zilboorg, Masculine and Feminine: Some Biological and Cultural Aspects, in id. at 96, 98-103 [hereinafter cited as Zilboorg].

10. E.g., H. Deutsch, 1 The Psychology of Women: A Psychonalytic INTERPRETATION 279-324 (1945). For a critique of the discriminatory standard, see B. FrIedAN, The FEMININE MYSTIQUe 126-35 (1963); Horney, The Overvaluation of Love, in Femmine Psychologx 182, 183 (H. Kelman ed. 1973); Hacker, supra note 4; Weisstein, Kinder, Kuche, Kirche as Scientific Law: Psychology Constructs the Female, in GonNG CRAZX (H. Ruitenbeek ed. 1972) [hereinafter cited as Weisstein].

11. This is Napoleon's famous bon mot, quoted by Freud and frequently repeated. Zilboorg, supra note 9, at 98. See J. RheINGold, The Fesr of Being a Woman 714 (1964); Erikson, Inner and Outer Space: Reflections on Womanhood, in THE WoMAN IN AMERICA 21 (R. Lifton ed. 1965) [hereinafter cited as Erikson].

Modified versions of the "anatomy is destiny" theory were espoused by a number of hospital administrators interviewed by the authors. Dr. Leon Epstein commented about the effect on the female personality of "the marked changes that women's bodies must undergo each month." Telephone interview with Dr. Leon Epstein, Associate Director, Langley-Porter Neuropsychiatric Institute, in San Francisco, California, November 15, 1973 [hereinafter cited as Epstein Interview]. Another adninistrator remarked that "since women have more sexuality than men, they are more frustrated." Interview with David Abrahams, M.D., Director, Psychiatric Program, Herrick Memorial Hospital, in Berkeley, California, November 8, 1973 [hereinafter cited as Abrahams Interview]. Dr. A. S. Iinn, Medical Director, Napa State Hospital, stated that manic-depressive psychosis might result from a sex-linked genetic defect. Interview with Dr. Linn, at Napa State Hospital, in Imola, California, November 27, 1973 [hereinafter cited as Iinn Interview]. The consensus apparently was that physiological differences somehow create psychological differences which psychiatrists must consider in dealing with patients, although this was stated simply as an assumption without empirical support. 
longing for the missing penis, ${ }^{12}$ who invented weaving and plaiting in an effort to duplicate the pubic hair which conceals their inferior genitalia. ${ }^{13} \mathrm{He}$ also believed that woman's social and psychological needs were fulfilled by bearing and rearing children. ${ }^{14}$ Carl Jung believed that woman's role was similarly limited and that a woinan who took up "a masculine calling, studying, and working in a man's way . . . is doing something not wholly in agreement with, if not directly injurious to her feminine nature."15 Even Alfred Adler, a strong advocate of equality of the sexes, espoused a "sensible" form of the traditional male-female "division of labor," in which "woman has taken over a certain part of the world's work [which might otherwise occupy a inan, too], in return for which man is in the position to use his powers to greater effect." 10

While these ideas are not necessarily believed by every clinician, and some contemporary therapists undoubtedly strive to eliminate bias from their contacts with clients, the influence of such beliefs on the psychiatric profession remains great. Indeed, observers have written that American clinical psychology and psychiatry inean, essentially, "endless commentary on and refinement of Freudian theory."17

Part of the explanation of psychiatry's ready acceptance of such theories may lie in the extent to which the psychological sciences have traditionally viewed the individual in isolation, divorced from his or her social context. ${ }^{18}$ Because the constricting social milieu in which

12. S. FreUd, Interpretation of Dreams, in Basic Writings of Sigmund Freud 306-09, 377-78 (A. Brill ed. 1938).

13. S. FreUd, NeW INTROdUCtoRy Lectures on Psychoanalysis 181 (W. Sprott transl. 1933).

14. S. Freud, Totem and Taboo, in Basic Writings of Sigmund FreUd 818 (A. Brill ed. 1938). Women judges and attorneys may be particularly interested to note that Freud also believed that "women have but little sense of justice, and this is no doubt connected with the preponderance of envy in their mental life. ... We also say of women that their social interests are weaker than those of men ..." S. Freud, New Introductory Lectures on Psychoanalysis 183 (W. Sprott transl. 1933).

15. C. Jung, Contributions to Analytical Psychology (1928), cited in ChesIER, supra note 9, at 77. See also Erikson, supra note 11.

16. ADLER, supra note 4, at 122, 129-33. For a discussion and analysis of the work of other promiment clinical theorists, see CHESLER, supra note 9, at 75-133.

17. Weisstein, supra note 10 , at 236 . Other commentators also note the pervasive influenee of Freud in Americau psychiatry. Milletr, supra note 5, at 241; Kaufman, Psychoanalysis and American Psychiatry, 43 PsYchIATRIC Q. 301 (1969).

18. Traditional theories of schizophrenia, for example, locate the search for causation in the individual. Research and treatment typically proceed in an isolated clinical environment, with little attempt made to probe environmental or social factors. E.g., S. Beck, Personaltry Structure IN Schizophrenia $73-79$ (1938) (regarding weak "psychic structure" of schizophrenics); L. Hinsie, The Treatment of SchizoPHRENIA (1930) (concerning treatment directed at the individual entirely divorced from context); Winder, Some Psychological Studies of Schizophrenics, in THE ETrology of 
woinen have existed has not adequately been taken into account, it has been common to see women's social behavior as the manifestation of a rigidly limited potentiality, rather than as a consequence of limited social opportunity. Masochism, for example, with its self-abasing symbolic behavior, was considered a feminine quality, resulting from female physiology. ${ }^{19}$ Similarly, a tendency appeared in inuch of clinical theory to presume that a woman must be a wife and mother, and cannot usefully or naturally be anything else. ${ }^{20}$ If she fulfills these roles and is still dissatisfied, she inay be perceived as maladjusted or mentally ill. If she does not conform to these social expectations, or if she insists upon doing something else in addition, her mental equilibrium may be called into question. ${ }^{21}$ If she is sexually active or insists on working despite her husband's objection, psychiatric authority may be called upon to intervene in support of the man's position. ${ }^{22}$

Even ostensibly sex-neutral theories can be distorted by the personal attitudes of the clinician into mechanisms for enforcing adherence to societal expectations. For instance, in a recent article two psychologists urged application of behavioral techniques in the treatmient of traffic offenders. ${ }^{23}$ Judges were urged, however, to adopt different treatment approaches for inale and female drivers, on the grounds that excessive speeding is "deviant" and "abnormal" for females, but not for males. These clinicians expressed the view that a judge who treated both inale and female offenders equally was mak-

SCHIZOPHRENIA 191 (D. Jackson ed. 1960) (concerning research in a purely clinical setting). More recently, theorists have begun to examine elements of the social context, in an effort to understand behavior which might appear irrational when viewed in isolation. E.g., R. Laing \& A. Esterson, Sanity, Madness aNd THE Family (1965). For a discussion contrasting the traditional, clinical point of view with a social or existential approach, see R. LAING, The Politics of Experience 70-90 (1967). For a critical view of the traditional approach, see Sarbin, Schizoplirenia Is a Myth, Born of Metaphor, Meaningless, Psychology Today, June 1972, at 18 [hereinafter cited as Sarbin]. For an excellent critique of the individualist perspective in psychology on a broader scale, see Weisstein, supra note 10.

19. Horney, The Problem of Feminine Masochism, in Psychoanalysis aND Women 21 (J. Miller ed. 1973).

20. See notes 14-17 supra and accompanying text.

21. Id.

22. Of conrse there are thousands of women who deviate from these narrow standards by virtue of their independent lifestyle, full- or part-time einployinent, or some other particular. And not all of these woinen are imprisoned on a charge of inental illness. The key seems to reside in the variables of status-power position and conflict. If the woman who deviates from socially accepted roles thereby coines into conflict with significant others in her life from an inferior status-power position, then psychiatric theory may be called upon to support the invalidation of her preferences with the authority of science. See notes 35-41 infra and accoinpanying text; note 92 infra (discussion of schizophrenia).

23. Anderson \& Whitman, The Control of Behavior Through Law: Theory and Practice, 47 NOTRE DAME L. Rev. 815, 833 (1972). 
ing a serious mistake "under the guise of presumed equality of treatinent for all." ${ }^{24}$ Thus, even an apparently neutral theory or technique, such as behaviorism, inay be interpreted and einployed in a discriminatory manner when the clinician is steeped in professional or cultural values that incorporate a belief in a limited female role.

Evidence also exists that clinical beliefs reflecting a sex-based bias are held by male and female practitioners alike. A recent study based on a questionnaire answered by 79 clinicians, 46 male and 33 female, indicated no significant differences among male and female clinicians with respect to attitudes about normal female behavior. ${ }^{25}$ The clinieians were asked to list traits felt to be characteristic of healthy males, healthy females, and healthy adults, sex unspecified. What was judged healthy for adults, sex unspecified, was similar to what was judged healthy for adult males, and correlated with previous studies of desirable social qualities as perceived by nonprofessional subjects. Healthy women, by contrast, were seen as more submissive, less independent, less adventurous, more easily influenced, less aggressive, less competitive, more excitable in minor crises, more easily hurt, more emotional, more vain, and less objective. ${ }^{28}$

The medical and scientific basis for such stereotypes is sparse, and studies which would support them appear to be methodologically suspect. One study, for example, conducted by Erik Erikson, compared the behavior of children in their early teens. ${ }^{27}$ The children were invited to create a scene from a movie using blocks, figures, furniture, and other props. Observing that many of the girls built enclosures depicting domestic scenes while many of the boys built towers or ruins, Erikson concluded that girls are preoccupied "by nature" with family tranquility while boys are concerned with rising to the heights of success and crashing down to ruin. ${ }^{28}$ For Erikson, this experiment supplied evidence of an "innate" difference in the psychology of males and females, even though by their early teens most children lave been substantially influenced by parents, scliool, and the popular media with respect to the "right" role for their sex. ${ }^{29}$ This same fallacy, of assum-

24. Id.

25. Broverman, Broverman, Clarkson, Rosenkrantz \& Vogel, Sex Role Stereotypes and Clinical Judgements of Mental Health, 34 J. Consultnvg \& Clinical PsYCHOLOGY 1 (1970) [hereinafter cited as Broverman, et al.].

26. Id. at 5 .

27. Erikson, supra note 11, at 1.

28. Id.

29. E.g., ADLER, supra note 4, at 127 :

If we compare the psychic states of boys and girls and seemingly find evidence in support of this classification, we do not deal with natural phenomena, but are describing the expressions of individuals who have been directed into a very specific channel, whose style of life and behavior pattern have 
ing that observed behavior, regardless of its social and historical context is a manifestation of biological necessity, characterizes much of the psychiatric and psychological literature about women. Other studies consist largely of intuitive "insights" supported by "years of intensive clinical experience," but fail to meet the rigorous methodological standards one might expect from scientific research. ${ }^{30}$

II

\section{Sex-Based Discrimination in Practice}

There is considerable evidence that sex-based discrimination in the psychiatric treatment of women is more than a theoretical possibility. Indications are that such discrimination appears in all three phases of incarceration for mental illness: admission, treatment, and release.

Since civil commitment statutes are almost invariably drafted in nonspecific language, ${ }^{31}$ their application becomes a function of clinical rather than legislative judgment. The absence of a clear statutory framework permits excessive reliance on psychiatric judgment and allows psychiatric stereotypes of women to predominate in the commitment process. One result, according to mounting evidence, is that women are treated differently from men, and in many respects more harshly. Although the evidence describing the manner in which men and women are treated at the hands of psychiatric chinicians is still incomplete, a preliminary assessment of the available information indicates that significant differences exist. ${ }^{\mathbf{3 2}}$ Institutionalized women are subjected to different treatment programs from those imposed

been narrowed down by specific conceptions of power... . . There is no justification for the differentiation of "manly" and "womanly" character traits.

30. For a discussion of the failure of psychiatric methodology with specific regard to women see B. Friedan, The Feminine Mystilue 126-35 (1963); Weisstein, supra note 10, at 233, 237; Weissten, Woman as Nigger, Psycholoox Todax, Oet. 1969, at 58. For a general discussion of the problem of methodology in psychiatry see MYth of Mental IllNess, supra note 3, at 1-8; Rogow, supra note 3, at 23-24; - Roth, et al., supra note 2, at 402-07; Vickers, Science and the Appreciative System, 21 Human Relations 99 (1968).

31. Thus, one can be committed for having "a psychiatric disorder which substantially impairs mental health," ARIz. REv. STATs. \$ 36-501(7) (Supp. 1973); for being "a danger to others, or to himself, or gravely disabled" as a result of mental disorder, CAL. Welf. \& INST'NS CODE $\S 5150$ (West Supp. 1974); for "mental disease to such an extent that a person so afflicted requires care and treatment," N.J.S.A. 30:4-23 (Supp. 1973-74); or for allegedly meeting some similar standard. See THE Mentally Disabled AND THE LAw (S. Brakel \& R. Rock rev. ed. 1971) [hereinafter cited as Brake1 \& Rock]; Livermore, Malmquist \& Meehl, On the Justifications for Civil Conmitment, 117 U. PA. L. Rev. 74 (1968).

32. Sẹe notẹs 37-86 infra ạnd açcompanying text. 
upon men ${ }^{33}$ and women seem to be the primary targets of such drastic techniques as lobotomy and psychosurgery. ${ }^{34}$

\section{A. Admissions}

Dr. David Abrahams, psychiatrist and Director of the Psychiatric Program at Herrick Memorial Hospital in Berkeley, has observed that "It's harder for men to get into the hospital, and it's easier for men to get out." 35 When the person accused of mental illness is a woman, sex-related factors frequently play a part in the initial decision to detain.

The decision is made by a staff physician or psychiatrist in many jurisdictions. $^{36}$ These personnel are virtually always men, ${ }^{37}$ and, regardless of sex, are likely to hold professional views and personal opinions that discriminate against women. ${ }^{38}$ This sex difference between the male physician and the female patient-inmate affects the decision to admit in ways that go beyond the perception of sex role stereotypes in diagnosis. For example, women who by tradition and training are weaker, unore subunissive, and anxious to please, are particularly vul-

33. See notes 57-81 infra and accompanying text.

34. See notes 77-81 infra and accompanying text.

35. Abrahams Interview, supra note 11.

36. E.g., "[W]ith the approval of the admitting officer," ALA. CODE tit. $45 \S 205$ (1) (2) (Supp. 1971); "The head of the hospital . . may receive . . . ." ALAs. Stat. $\S 47.30 .020$ (Supp. 1971); "If in the judgment of the professional person in charge of the facility providing evaluation and treatment, or his designee, the person can be properly served without being detained, he shall be provided evaluation, crisis intervention, or other inpatient or outpatient services on a voluntary basis," CaL. WELF. \& INST'NS CODE $\$ 5151$ (West 1972).

37. In 1970, only nine per cent of persons receiving an M.D. degree were women. U.S. Office of Education, Earned Degrees Conferred: 1969-1970, Part A-Summary Data, cited in Social \& Economic Statistics Admin., Bureau of the Census, U.S. Dep't of Commerce, Statistical Abstract of the United States 133 (1972). Although we have no statistics on the numbers of male and female psychiatrists, staff lists from Bay Area institutions indicate that there are approximately the same percentage of woinen psychiatrists as women M.D.'s. The psychiatric staff of Herrick Memorial Hospital has only nine per cent women. Staff list, Herrick Memorial Hospital, Berkeley, California, October 1, 1973 (on file with the Center for the Study of Legal Authority and Mental Patient Status, P.O. Box 822, Berkeley, California 94701). The psychiatric staff at Napa State Hospital includes only 14 per cent women. Interview with Ms. Dorothy Owens, Personnel Officer, Napa State Hospital, in Imola, California, November 27, 1973. At Highland Hospital, both psychiatrists on the in-patient service are men. Interview with Susan Mandel, Pli.D., Chief of In-Patient Service, Highland Hospital, in Oakland, California, January 25, 1974 [hereinafter cited as Mandel Interview]. The psychiatric staff at Langley-Porter Neuropsychiatric Institute includes only 10 per cent women. Teleplone interview with Ms. Emmy Baidwan, Adıninistrative Ass't II, Langley-Porter Neuropsychiatric Institute, in San Francisco, California, February 1, 1974.

38. Broverman, et al., supra note 25. See notes 11-20 supra and accompanying text. 
nerable to pressure from male authority figures. Thus the distinction between voluntary and involuntary admissions, already blurred by the existence of alternative coercive procedures, may be effectively eliminated. $^{39}$ Furthermore, a hospital administrator has observed that male psychiatrists identify more easily with males, and may therefore tend to accept the perceptions of the husband, father, or policeman seeking a woman's commitment, and either ignore or be less sensitive to the woman's version of the facts. ${ }^{40}$ Male admitting clinicians may also tend to admit women more readily than men because of their personal feelings of "sympathy" and "protectiveness" toward women. ${ }^{41}$

Particular groups of women are far more vulnerable to cominitment than their male counterparts. Disobedient or runaway adolcscent females are more likely to be institutionalized for their behavior than similar adolescent nuales. ${ }^{42}$ Adolescent boys who run away are more likely to be viewed as misguided, or as merely "sowing wild oats," than as sick. ${ }^{43}$ Sexually active adolescent females are more likely to be institutionalized than sexually active males. Such behavior on the part of females is less socially acceptable and, if pregnancy results, impossible to conceal. ${ }^{44}$ Sexually active adult women are also

39. See generally Gilboy \& Schmidt, "Voluntary" Hospitalization of the Mentally Ill, 66 Nw. U. L. Rev. 429 (1971) [hereinafter cited as Gilboy \& Schmidt]. The distinction between voluntary and involuntary admission often disappears altogether after the patient-inmate requests release. In inany jurisdictions, even though a person has been admitted under a voluntary provision, a request for release may be denied for a specified period of time during which proceedings may be instituted for involuntary commitment. E.g., CoNN. Gen. Stats. ANN. \$ 17-187 (Supp. 1973) (voluntary patient may be held 10 days after request to leave while superintendent files petition for continued commitment).

One psychiatrist has suggested that so-called voluntary admissions often result from the institution indicating to the patient that, "If you don't go to the hospital by signing this piece of paper, then we'll get you in by having someone else sign another piece of paper." Statement of Dr. Thomas S. Szasz, Hearings on the Constitutional Rights of the Mentally Ill Before the Subcomm. on Constitutional Rights of the Senate Comm. on the Judiciary, 87th Cong., 1st Sess., at 265 (1961).

40. Abrahams Interview, supra note 11.

41. Interview with Mrs. Carla Rosenlicht, Chief of Rehabilitation Services, Highland Hospital, in Oakland, California, January 25, 1974 ("Admitting personnel may feel that psychotic women are more likely to be sexually exploited, and are more rehabilitable than men"); Linn Interview, supra note 11 ("Male clinicians prefer to work with women and are more protective toward women"); Abrahams Interview, supra note 11 ("Admitting physicians indulge in rescue fantasies concerning women patients; women have more easily met dependency needs").

42. Intervicw with David Abrahams, M.D., Director, Psychiatric Program, Herrick Memorial Hospital, in Berkeley, California, November 16, 1973.

43. Id.

44. Id. Dr. Chesler cites a startling illustration of this point:

A widening wave of shocked horror is sweeping Britain following disclosure that two sane women were kept confined in a mental hospital for about 50 years each simply because they had borne illegitimate children. ... The women's parents went to local governinent officials for help with their "way- 
more likely to be institutionalized than sexually active men if parenis or husbands object.45

Women involved in custody suits are another target for institutionalization. A renowned forensic psychiatrist has observed that when the sanity of a parent is at issue in a custody suit, it is almost always the mother's sanity that is questioned. ${ }^{46}$ This may be explained by the fact that in inost jurisdictions, the nother is usually awarded custody of young children unless there is proof of her unfitness. ${ }^{47}$ Fathers or grandparents seeking custody may seek to create proof of the mother's unfitness by hospitalizing her for mental illness. As was observed earlier, male admitting clinicians tend to be nore responsive to the perceptions of husbands and fathers seeking a woman's commitment, and even in jurisdictions that require the approval of an admitting officer, the recommendation of the head of the household is often

ward" daughters and, Sheridan said, "the local authority to whom the parents turned did not have a department to deal with unmarried mothers." . . . Miss Baker was 23 when committed to the hospital in 1921; Miss Kitson was 22 when committed in 1928.

New York Post, May 27, 1972, cited in CHESLER, supra note 9, at 162.

A state hospital administrator noted that every girl in the hospital's adolescent ward had a "record" of promiscuity. Linn Interview, supra note 11.

45. For example, a Bay Area attorney described the case of a yonng woman who lived with a man despite the strong disapproval of her mother. The mother invited her daughter to lunch, then planted drugs in her purse and caused her to be arrested. The woman was brought to the state mental hospital and charges were dropped. When her male friend came to the hospital to visit her and protest what he considered to be her kidnaping, the psychiatrist decided the friend was an unsettling influence who should be prohibited from visiting her again. The staff psychiatrist handling the case privately admitted to the attorney that the manner of the woman's incarceration was "shady and regrettable;" nevertheless, he felt she should not be permitted to come under the influence of either the mother or her male friend. Conservatorship proceedings were instituted so that the hospital could retain control of the woman's life. The woman was released almost immediately after her attorney informed the hospital that she was being held illegally. Interview with David Cobin, attorney at law, in Berkeley, California, March 12, 1974.

46. Lecture by Martin Blinder, M.D., Hastings College of the Law, in San Francisco, California, November 20, 1973. See also Malmquist, The Role of Mental Illness in Custody Proceedings, 2 FAMILY L.Q. 360, 365-70 (1968) (all cases discussed refer to mental illness of the mother only); Podell, Peck \& First, Custody-To Which Parent?, 56 MARQ. L. REv. 51, 61-63 (1972) [hereinafter cited as Podell].

47. An investigator reports that mothers are awarded custody in 90 per cent of the cases. Drinan, The Rights of Children in Modern American Family Law, $2 \mathrm{~J}$. FaMILY L. 101, 102 (1962). This is due largely to the generally accepted principle that children of "tender ages" should remain with their mother if she is fit. Bregman, Custody Awards: Standards Used When the Mother Has Been Guilty of Adultery or Alcoholism, 2 FAMILY L. Q. 384, 404 (1968); Comment, Conflicting Custody Decrees: In Whose Best Interest?, 7 DuQuesne U.L. Rev. 262, 265 (1968-69). But see Podell, supra note 46 , at $54-56$, for a discussion of the recent trend toward giving equal preference to both parents. Although granting virtually automatic custody to the mother is itself a form of sex-based discrimination, incarcerating the mother to deprive her of custody is hardly the appropriate remedy. 
undisputed.48 A woman thus committed who subsequently seeks custody of her children may find it difficult to overcome the handicap of her "history of mental illness." 40

Another group of women who become subject to institutionalization because of factors related to sex are single mothers, especially single mothers receiving financial assistance from the state. These women are completely dependent financially, and because of their dependence various governmental agencies deinonstrate considerable interest in the manner in which they live. ${ }^{50}$ Often this surveillance takes the guise of concern "for the welfare of the child." Single mothers whose mode of life arouses the suspicion of their caseworkers often find themselves subject to requests that they submit to psychiatric counseling as a condition of receiving further welfare support. ${ }^{51}$ In extreme cases, the offending wornan may be committed and her child placed in a foster home. ${ }^{52}$

Finally, persons in an inferior economic position are particularly vulnerable to institutionalization. In American society, fewer women than men work, and even fewer hold positions of respect and authority, or are the sole support of their families. ${ }^{53}$ The impact of economic

48. See notes 55-56 infra and accompanying text.

49. A case related by a San Francisco attorney exemplifies this process. The mother of a young woman wanted to obtain custody of the woman's two children. She arranged for her daughter's hospitalization, according to a sister who retained legal counsel on behalf of the daughter, by beating the daughter severely, taking her to a mental hospital, and describing the injuries as self-inflicted. The hospital authorities believed the mother, and the young woman was diagnosed as "gravely disabled" and slated for conservatorship. Although she was released soon after her counsel asserted her legal rights, she still has not been able to regain custody of her children. Telephone interview with Robert Bunker, attorney at law, in San Francisco, California, March 13, 1974.

50. See Jarrell, Poverty Law_Is a Search Warrant Required for Home Visitation by Welfare Officials, 48 N.C.L. REv. 1010 (1970); Reich, Individual Rights and Social Welfare, 74 YALE L.J. 1245, 1251 (1965); Willcox, Patterns of Social Legislation: Reflections on the Welfare State, 6 J. OF PUB. L. 3, 7 (1957) ("It behooves us to be constantly on our guard lest, out of zeal to better people's lot, we impose upon them patterns of behavior in matters which, under our scheme of things, government ought not to meddle").

51. Abrahams Interview, supra note 11. An unmarried welfare mother reported that she did not get aloug with her social worker. When the social worker thrcatened to terminate the woman's welfare payments, she expressed alarm, since loss of welfare posed the threat of starvation and homelessness for herself and her two children. The social worker responded, "If you can't coutrol yourself better you are obviously incapable of taking care of yourself and you certainly are unfit to take care of the children. You know what I mean." Interview with A.J., in Albany, California, March 1, 1974.

52. See id.

53. In 1971, 19,370,000 more men than women were employed, and thoy earned, on the average, $\$ 62$ more per week than did women. Social \& EConomic Statistics Admin., Bureau of the Census, U.S. Dep't of Commerce, Statisticat Abstruct of the UNITED States, 219, 220, 227, 228, 233, 234, 245 (1973). Several hospital 
status on admissions is, therefore, considered as a sex-related factor. Financial imdependence affects admissions in many ways. For example, society has less opportunity and less motivation to interfere with a man supponting himself and, possibly, his family. In consequence, admitting physicians are less likely to institutionalize a man than a woman who evidences an identical set of symptoms which, although not incapacitating, nevertheless would be considered to call for treatment.

Furthermore, when family conflict is a factor in the commitment decision, disagreements tend to be resolved in favor of the person in the superior economic status position. ${ }^{54}$ In a family where the husband pays the bills, his wishes are bikely to be given great weight. Of course, a family member's recommendation is not always followed automatically; the psychiatrist and the judge theoretically exercise an independent judgment.55 Unfortunately, however, their independence is often more apparent than real, and the recommendation of the head of the household may therefore be dispositive. ${ }^{56}$

\section{B. Treatment}

Institutional treatment of women often involves conditioning in and enforcing of sexual stereotypes. ${ }^{57}$ Even clinicians who agree that

administrators agreed that men are less likely to be admitted to mental institutions because they are more likely to be employed. This was explained in two ways: (1) "Work is therapeutic," Abrahams Interview, supra note 11; Linn Interview, supra note 11, and (2) "Hospitalization of the male wage earner is a greater disruption to the family," Interview with R.P. Daw, Ph.D., Program Director, Program V, Napa State Hospital, in Imola, California, November 27, 1973 [hereinafter cited as Daw Interview]; Epstein Interview, supra note 11; Linn Interview, supra note 11.

54. See generally Gilboy \& Schmidt, supra note 39, at 434-37 (concerning hospitalization in "an overwhelming majority of cases" of persons brought to the hospital by police at the request of a family member); Ellis, Volunteering Children: $P a$ rental Commitment of Minors to Mental Institutions, 62 CALIF. L. REV. 840 (1974) (concerning the commitment of minors on the recommendation of their parents).

55. E.g., note 36 supra; "If the court or jury finds that the person named ... [presented imminent danger to others] the court shall remand him to .... [the designated facility]," CAL. WeLF. \& INST'NS CODE $\$ 5304$ (West Supp. 1974); "[T]he court ... may, if satisfied that the patient requires continued retention for care and treatment, .... immediately issue an order authorizing continued detention . . .," N.Y. Mental Hygiene Law $\$ 73$ (McKinney 1971).

56. E.g., Ellis, Volunteering Children: Parental Commitment of Minors to Mental Institutions, 62 CALIF. L. REv. 840, 864 (1974) (this issue).

57. A classic study of the use of psychiatry to bring about the "adjustment" of the woman to her historical position is the case of Zelda Fitzgerald, wife of the novelist F. Scott Fitzgerald. Although she was a gifted author in her own right, her husband discouraged her writing, using her material instead as the basis for some of his own work. As a result Zelda took up ballot and danced professionally on several occasions. Scott believed that Zelda's dancing led her to sexual coldness toward him and neglect of her domestic duties and their child, and was responsible for his alcoholism. Shortly thereafter, Zelda was incarcerated im a mental institution for over three years, 
rigid sex role distinctions are only the product of culture often state that since social adjustment is the goal of therapy, treatment should be aimed at encouraging patient-inmates to adopt "appropriate" social roles. $^{58}$ Conditioning may take the form of encouraging or requiring women to wear skirts and nylons, or of providing instruction in fashion and the use of cosinetics. ${ }^{59}$ Female inmates at Haverford State Hospital are required to earn tokens to pay for their meals, bed, and use of the day room. To earn tokens, woinen must change their underwear, make the beds in the men's wards, perform housekeeping chores, or wear a girdle. ${ }^{60}$

her artistic ambitions characterized by the doctors as "self-deceptions" responsible for the conple's marital problems. She was not permitted to leave the institution until she passed several tests of her abihity to adjust to her life with Scott and her children. N. MILFORD, ZELDA: A BIOGRAPHY 190-91 (1970).

For other examples of the psychiatric enforcement of sexual stereotypes, see Heilbrun, Sex Role, Instrumental-Expressive Behavior, and Psychopathology in Females, 73 J. Abn. Psychol. 131, 132 (1968), citing T. Parsons \& R. Bales, Family, Socialization and Interaction Process (1955); Modlin, Psychodynamics and Manngement of Paranoid States in Women, 8 ARch. Gen. Psychiat. 263 (1963). In the Modlin study, Dr. Herbert C. Modlin treated five "paranoid" women by "managing" them into submissive "feminine" roles. The women "fancied" that men were persecuting them. Dr. Modlin advised his colleagues to disregard their patients' "distorted perceptions" and substitute their own "acknowledged authority." The study concludes that "[t]he disappearance of delusions coincided with . . . onr helping her to reassert her feminine social role." Id. at 267.

58. "If coping with or maintaining homeostasis in our socicty" is mental health, "then it is different for men and women." Abrahams Interview, supra note 11.

Similar views were expressed by other administrators. Daw Interview, supra note 53; Mandel Intervicw, supra note 37. "As long as the adoption of culturally prescribed masculine or feminine sex-role behaviors receives systematic social reinforcement, there is reason to expect psychological adjustment to vary with appropriate attainment of masculine or feminine sex-role identity." Heilbrun, Sex-Role, Instrumental-Expressive Behavior, and Psychopathology in Females, 73 J. ABN. PsychoL. 131, 131 (1968). But at least one highly respected clinician believes that "modifying the individual to suit the environment should be frowned upon" by psychiatrists, because the "individual is above society." Interview with Portia Bell Hume, M.D., Director, Psychiatric Residency Training, Herrick Memorial Hospital, in Berkeley, California, Novcmber 16, 1973.

59. ChesLer, supra note 9, at 226; Interview with Ms. Ann Grogan, in San Francisco, Cahfornia, November 14, 1973; Interview with David Abrahams, M.D., Dircctor, Psychiatric Program, Herrick Memorial Hospital, in Berkeley, Califoruia, November 16, 1973; Daw Interview, supra note 53; Linn Interview, supra note 11. Napa State Hospital has an extensive "beauty" program for women, including hairstyling, cosmetics, jewelry, color coordination, and fabric selection and care. Linn Interview, supra note 11.

A law student who committed herself to Boston State Hospital in a recent year as part of a class project reported that women were given instruction in the use of cosmetics and clothing as part of their therapy. Men received no comparable instruction. Interview with Ms. Jnne Moroney, in San Francisco, Califoruia, June 18, 1972.

60. Their girdles must be new, however; an old one will not entitle the wearer to receive tokens. Levering, She Must Be Some Kind of Nut, Rough Times, September 1972, at 3 [hereinafter cited as Levering] (on file with the Center for the Study of Legal Authority and Mental Patient Status, P.O. Box 822, Berkeley, California 
Many institutions require women patient-inmates to perform domestic labor in the institution, and occasionally, in the doctors' homes. ${ }^{61}$ If the women refuse to work, they can be punished with drugs, shock, and longer imcarceration. If they accept and perform well, the staff may be reluctant to let them go. ${ }^{62}$

But not all role conditioning takes such mild forms. At times, "therapy" designed to force wonen into the conventional inold for their sex can be cruelly and openly coercive. For example, an informant reported that his niother, who had suffered a nervous breakdown, finally "got so bad she forgot how to cook." After receiving a few electroshock treatnients, however, "she remembered like inagic." 3 Similarly, woinen patients who persist in demonstrating anger or aggressiveness are considered to be so deviant that isolation, confinement in strait jackets, or even shock therapy is prescribed. ${ }^{64}$ Submissiveness and obedience are also demanded of inale patient-inmates, of course. But it appears that women, unlike men, are singled out and punished for mildly aggressive behavior which would be tolerated in men, simply because they depart from the clinician's expectations for "normal" wolnen. ${ }^{65}$

94701).

At Napa State Hospital in California, the Christmas gift suggestion list approved by the hospital reveals another form of role indoctrination. The men's list is composed entirely of practical items such as socks and shirts. The women's list, in contrast, is much longer and is composed almost entirely of make-up, cologne, hair spray, and similar items. Christmas Gift Suggestion List, Napa State Hospital (on file with the Center for the Study of Legal Authority and Mental Patient Status, P.O. Box 822, Berkeley, California, 94701).

61. Levering, supra note 61; Daw Interview, supra note 53. Dr. Daw remarked that making beds was the proper therapy for housewives. He also advocated "implosive therapy," which involves giving depressed patients, the great majority of whom are women, Nat'l Inst. of Mental Health, Mental Health Statistics, ANalytical \& Special Study Reports, Series B, No. 5, The Mental Health System-1971 48 (1973), useless, repetitive tasks "like cleaning the same place over and over again" and then expressing unwarranted dissatisfaction with the results, to provoke the patients' anger. Id.

62. ChesLer, supra note 9 , at $160,168$.

63. Interview with B.D., in Berkeley, California, October 1971. For a chilling experiential description of electric shock "treatment," see Field, Terror on Tuesdays and Thursdays, in The White SHIRTS 5-8 (1964) (on file with the Center for the Study of Legal Authority and Mental Patient Status, P.O. Box 822, Berkeley, California 94701). See also Roth et al., supra note 2, at 435-36.

64. Chesler, supra note 9, at 36. In one reported incident, researchers attempted to reduce aggressive behavior in a female immate by shocking her repeatedly with a cattle prod whenever she made verbal threats or committed aggressive acts. Ludwig, Marx, Hill, \& Browning, The Control of Violent Behavior through Faradic Shock: A Case Study, 148 J. Nervous \& Mental Diseases 624, 627 (1969). While this "experiment" was, it is hoped, somewhat unusual, it serves to illustrate the extremes to which the dynamics of sex-based stereotyping may go when the victim is in the powerless position of a mental patient.

65. Abrahams Interview, supra note 11. 
While repression of sexual feelings and behavior is typical in mental institutions for men and women, it is particularly strict for women. ${ }^{66}$ Women are more likely than men to be initially referred to mental institutions for "sexually acting out;" 67 and men who seek to satisfy their sexual impulses while in the institution are more likely than women to be regarded as engaging in normal behavior. A law student who worked as an intern with the Mental Health Information Service in New York describes the case of a woman in a New York institution who was given shock treatment for "sexually acting out." At a hearing on her competence to deny consent to further shock, the physician who authorized the treatment wrote to the court that "since the patient's behavior in the ward was so mappropriate and bizarre that she was allowing herself to be used sexually by the malc patients, the administration of Electro-Convulsive treatment was a matter of emergency." Apparently, the doctor did not consider the men who responded to the woman to be acting inappropriately; they received no punishment, or "corrective therapy," at all. ${ }^{\circ 8}$ Another young woman, committed by her parents, also had a diagnosis of "sexually acting out." The physicians had noted on her records, "if not hospitalized might get pregnant or get VD." Upon admission she was confined to the locked ward for two weeks. ${ }^{60}$ In another incident, hospital administrators discovered a couple engaged in sexual intercourse on the ward. The female was a 15-year-old woman diagnosed as schizophremic. The man was a much older patient-inmate who had been admitted as a "danger to society." As a result of the imcident, the man was released from the hospital "to remove him from the situation," while the woman was sent to seclusion. ${ }^{70}$

Although displays of aggressive sexual behavior by female inmates are often severely punished, women patients have been the victims of sexual abuse by male institutional personnel. ${ }^{71}$ Dr. Chesler

66. Chesler, supra note 9 , at 36-37.

67. Men engaging in similar activities, exhibitionism and nudity, for example, are more likely to be sent to jail. Daw Interview, supra note 53, Dr. Russell Eisenman of Temple University noted that the term "sexually acting out" is usually applied only to women, in a condemnatory manner. Letter from Russell Eisenman in 5 Social ACtion: NeWSLETTER OF PSYchologists for Social Action 3 (January 1972).

68. Interview with Ms. Ann Grogan, in San Francisco, California, November 14, 1973. The instant case was reported without reference to the detailed facts involved, in New York City Health \& Hosp. Corp. v. Stein, 70 Misc. 2d 944, 335 N.Y.S.2d 461 (Sup. Ct. 1973).

69. Cekala, If This Be Insanity, Rougr TrMes, September 1972, at 2 (on filc with the Center for the Study of Legal Authority and Mental Patient Status, P.O. Box 822, Berkeley, California 94701).

70. Intervicw with P.R., in Berkeley, California, November 14, 1973.

71. Ceresler, supra note 9, at 170. An ex-inmate of Napa State Hospital reported that during the physical examination following her admission, the physician 
notes a number of reports from 1968 to 1970 of forced prostitution, rape, and impregnation of female mental patients by the professional and nonprofessional staff of the institutions in which the women were imprisoned. ${ }^{72}$ An investigation of New Jersey's largest mental institution revealed a variety of sexual abuses mcluding rape of female inmates by staff personnel and use of women patients as prostitutes for the benefit of male employees. ${ }^{73}$

In addition to such abuses, mcarcerated women may be made to suffer forced maternity. A recent study documents $a_{1}$ threefold imcrease in the rate of pregnancy and dehvery among psychiatrically incarcerated women in Michigan state mental institutions from 1936 to 1964. Nevertheless, a majority of the responding institutions refused to prescribe contraceptives or perform abortions. ${ }^{74}$ One administrator reported that if a female inmate desired to have an abortion, a panel of physicians would probably have to determine whether or not the patient was capable of deciding that she did not want to give birth. If they judged her incapable of making such a decision, she would be forced to carry the baby to term. ${ }^{75}$ This reasoning, of course, overlooks the rather obvious point that an incarcerated woman who wanted an abortion might be making a very sensible decision, both practically and psychologically.

Sex-based differences are also manifested in inore frequent resort to the most drastic type of treatment, psychosurgery. ${ }^{76}$ A successful psychosurgical procedure destroys the bram's capacity to respond emotionally, and impairs the functions of insight, creativity, judgment, and, occasionally, control of bodily funotions. ${ }^{77}$ Approximately three times

questioned her minutely regarding her sexual experience and then remarked "with a leer" that he would like to work with her on improving it. Interview with Samantha D., in Berkeley, California, December 11, 1972.

72. Chesler, supra note 9 , at 37.

73. New York Times, March 24, 1969, §1, at 37, col. 5, cited in Rogow, supra note 3, at 183.

74. CHESLER, supra note 9, at 37-38.

75. Abrahams Interview, supra note 11. Other hospital administrators concurred. Daw Interview, supra note 53; Epstein Interview, supra note 11. In California, if the woman has a conservator, the conservator decides whether she may have an abortion. If she has no conservator, and doctors think she is unable to make a rational choice, conservatorship proceedings will be instituted and a conservator appointed. Linn Interview, supra note 11.

76. While a number of variations on the original lobotomy have been developed, "lobotomy" remains in use as a generic term for a variety of psychosurgical procedures performed under different names. The term is so used herein. The essential feature these operations have in cornmon is the destruction of healthy brain tissue for the purpose of altering behavior. Regarding lobotony, see generally Breggin, The Return of Lobotomy and Psychosurgery, 118 CoNG. REC. 5567 (1972) [heremafter cited as Breggin].

77. Id. at 5567, 5571. 
as many women as men have received psychosurgery. ${ }^{78}$ One psychiatrist observed that after a lobotomy "women do the dishes better, are better housewives and comply with the sexual demands of their husbands . . . . It takes away their aggressiveness."79 At least one psychosurgeon operated on women whose only "symptoms" were hostility to the husband, participation in community affairs, perception of the world as "fearsome and threatening," "inappropriate thinking," and mability to have children. This surgeon neasured the success of his operations by the subject's return to "normal" activities, including taking care of her house and children. ${ }^{30}$ The implications of such operations are apparent: women can be effectively domesticated, reduced to the status of useful, submissive, and cooperative objects.

\section{Release}

The sex-based discrimination present in diagnosis, admissions, and treatment often persists throughout the patient's period of detention, coloring the psychiatrists' perceptions of "cure" and affecting their decisions about release. A study of 206 white female patients classified them with respect to six factors: "treatability," family status, age, length of stay, education, and type of skill (i.e., professional, skilled, domestic worker, artistic skills only, poor worker, never employed). ${ }^{81}$ The researchers found that age, medical diagnosis, and treatment had no significant effect on the release rate. ${ }^{82}$ Factors that did improve a female inmate's chance for obtaining a discharge were a limited education, possession of doniestic skills only, having a spouse or immediate family, and length of stay. ${ }^{83}$ In short, married or family wonien, with little or no education, and possessing only household skills, were considered more appropriate subjects for discharge than their better educated and professional counterparts.

A recent study noted that female immates diagnosed as schizophrenic were adjudged to have improved their condition if they

78. Id. at 5571 .

79. Stein, The Maverick Therapist Shatters "Mad" Image, San Francisco Chronicle, December 7, 1972, § 1, at 41, col. 1 (quoting Dr. R.D. Laing). For a discussion of the use of psychosurgery to enforce sex role stereotypes, see Roberts, Psychosurgery: The Final Solution to the Woman Problem, Rougr Times, September 1972, at 16 (on file with the Center for the Study of Legal Authority and Mental Patient Status, P.O. Box 822, Berkeley, California 94701).

80. Brown \& Lighthill, Selective Anterior Cingulotomy: A Psychosurgical Evaluation, 29 J. NeURosurgery 513 (1968); Address by Hunter Brown ("Multiple Limbic Targets for Schizophrenia and Aggression"), American Psychiatric Association, May 10, 1973. Dr. Brown reports that 71 per cent of his subjects are women.

81. Orr, Anderson, Martin, \& Philpot, Factors Influencing Discharge of Female Patients from a State Mental Hospital, 111 AM. J. PsYchut. 576 (1955).

82. Id. at $579-80$.

83. Id. at 579. 
adopted a "feminine pattern" of low ego-strength coupled with high anxiety, as opposed to a "masculine pattern" of high ego strength and low anxiety. ${ }^{84}$ Women were found to be more likely to be released if they appeared weak-willed and anxious, as such behavior conformed to the clinicians' notion of an acceptable female person.

Such factors as the male physician's "rescue fantasies," "sympathy," and "protectiveness" for the female inmate all affect the possibility of release as well. Psychiatric supervisors have observed that many male clinicans prefer to work with women, are more protective toward women, and in some instances may be reluctant to see them leave the institution before they are "fully cured."85 Such attitudes, stemming from the male clinician's internalized belief about the role of man as woman's protector, may have the effect of prolonging the woman's institutionalization and inaking her release more difficult to achieve.

\section{III}

\section{The "Mental Illness" Model: An Inadequate Basis for SEX-BASED DisCRIMINATION}

In our mental health institutions we have created what is essentially a government; and it is a government not of laws, but of men, and occasionally of women. But the primary problem is not the sex of those who govern, or their race, economic status, or cultural background, though each of these characteristics may be important. Rather, it is that in labelling complicated human behavior patterns as manifestations of mental illness, and in authorizing the incarceration of individuals on the basis of "medical" diagnosis rather than an explicitly norniative standard, we have created a form of authority which is in primciple personal rather than legal. ${ }^{86}$ This system has proved virtually impervious to external supervision, because only qualified experts are deemed capable of knowing when it is functioning properly. The

84. Distler, May, \& Tuma, Anxiety and Ego Strength as Predictors of Response to Treatment in Schizophrenic Patients, 28 J. Consulting Psychol. 170, 170-77 (1964).

85. See note 42 supra. Psychiatrists also consider the situation into which the inmate will be released. A male patient is more likely to have financial resources, and therefore a greater opportunity to achieve existence independent of the institution. Abrahams Interview, supra note 11; supra note 53.

86. A South Dakota Board of Mental Illness, finding that the definition of "mental illness" in the state statute conveys no meaning and contains no standard by which the board could act, stated that "it is inappropriate to have a vague and indefinite definition and therefore to leave the enforceinent of mental illness [laws] up to the differing ideologies, passions, and prejndices of the individual judges, prosecutors, or psychiatrists." In re Marti, 7 Clearinghouse Rev. 689, 690 (S.D. Bd. of Mental Illness, Pennington County, January, 1974). 
occasional requirement of a finding of "dangerousness" disability," $\$$ the use of some courtroom formalities and an occasional trial by jury, combine to add the appearance of a social perspective; but the ultimate standard remains nominally medieal, its application a function not of community judgment but of faitl in the "professional expertise" of state-certified plysicians. ${ }^{80}$

All of this miglit be defensible as a delegation of authority by the community if the conceptual cornerstones of the theory on which these practices are premised leeld up under examination. But the theory that certain forms of illness-mental diseases-afflict persons in ways which undermine the faculties of reason and nuake the person incapable of exercising independent judgment has come under sharp attack. Those who challenge "the myth of mental illness" do not, of course, deny the existence of functional disabilities with no apparent organic origin. ${ }^{30}$ Their point is that there is no persuasive evidence that eccentric, bizarre, or dysfunctional behavior is the product of a "mental disease" in the sense that organic disease is the product of tumorous growth, viral infection, or the like. ${ }^{91}$ Moreover, the inher-

87. E.g., CAL. Welf. \& INST'NS CODE $\$ 5150$ (West Supp. 1974).

For a discussion of "dangerousness" as a criterion for incarceration, see M. CliNARD, Sociology of Deviant BeHAVIor 425 (1957); Bimbaum, A Rationale for the Right, 57 Geo. L.J. 752, 767 (1969); Brakel \& Rock, supra note 31, at 39; Dershowitz, The Psychiatrist's Power in Civil Commitment: A Knife that Cuts Both Ways, PsYCHOLogy TODAY, Feb. 1969, at 43; Gupta \& Kumasaka, Lawyers and Psychiatrists in the Court: Issues on Civil Commitment, 32 Mp. L. Rev. 6, 10-21 (1972); Livermore, Malmquist \& Meehl, On the Justifications for Civil Commitment, 117 U. PA. L. REv. 75, 81-83 (1968).

88. E.g., CAL. WeLF. \& INST'NS CODE $§ 5150$ (West Supp. 1974).

89. The test in California, for example, is whether a person "as a result of montal disorder is a danger to others, or to himself, or gravely disabled . ..." CAL. WeLF. \& INST'NS CODE $\$ 5150$ (West Supp. 1974). Thus dangerousness and grave disability are grounds for commitment in California only in conjunction with a finding that these factors are the result of a "mental disorder."

90. Such difficulties have beeu characterized as problems in living or coping (from the individual perspective), or perhaps as breakdowns in communication. For the development of several alternative conceptual models, see MYTH of MENTAL ILLNESS, supra note 3, at 115-308. For the presentation of a sociological theory, sce SCHEFF, supra note 3.

91. The example of schizophrenia will serve to illustrate our larger point about the vagueness and inadequacy of psychiatric labels. In 1967, 49.2 per cent of the resident patients in public hospitals were diaguosed as suffering from one of the schizophrenic reactions. G. Koons, Projected Age-Diagnostic Composition of the Resident Patient Population in State and County Mental Hospitals-1973, in NATIONAL INSTTtute of Mental Health, Statistical Note 8, Survey and Reports Section, at 5, figure 1 (1969), cited in Chamhers, Alternatives to Civil Commitment of the Mentally Ill: Practical Guides and Constitutional Imperatives, 70 MrCH. L. Rev. 1107, 1130 n.101 (1972).

To speak of a search for the causes of schizophrenia-be they genetic, environmental, biological, or some combination thereof-is to presuppose that there is indeed some concrete phenomenon or event to be explamed. A theory to explain schizophre- 
ent vagueness of many of psychiatry's diagnostic terms makes it easy for the clinician to conceal, even from himself, political and cultural preferences in the guise of neutral and detached judgments about objectively verifiable disease. To continue an example that has been mentioned earlier, "sexual acting out" is found in a number of women, particularly those diagnosed as schizophrenic. But "sexual acting out" may inean merely a woman's desire to have normal sexual relations with a man.2 That this behavior is noticed at all, and called a "symptom," is a reflection of the cultural values of the clinician rather than the discovery of some objectively existing disease-state.

Other diagnostic terms that have not been entirely translated into pseudo-medical terminology betray this subjective orientation more

nia might begin, for example, with the hypothesis that schizophrenia is caused by a combination of genetic and environmental factors. A medical analogy would be, "These feelings of nausea, fever, and so on are caused by a viral infection." But in the latter case, the events involved-nausea, vomiting, and so on-are objectively apparent, and viral infection is offered as an explanation for these phenomena. This theory may be tested by attempting to find the virus which is allegedly causing the disturbance. The former case, however, has a very different logical and scientific status. "Schizophrenia" is itself a theory, not a fact; but the term is employed as if it were a fact, or a reference to a clear set of facts requiring scientific explanation. In other words, beginning with the observation of behaviors which puzzle the observer, a theory is devised, and the name schizophrenia is given to the puzzling phenomenon. But since the puzzling behavior is itself intangible, each person applying the label has substantial freedom to use it with regard to whatever behavior puzzles him or her. Such theorizing and labeling is a highly personal process. Professor Chambers concludes:

No universally accepted chemical criteria exist for the diagnosis of "schizophrenia"; so far as I have ever been able to perceive, the label of "schizophrenia" is applied to persons whose views of themselves or external facts differ from the views of others and who often behave in a manner frightening to others but consistent with their "distorted" view of reality.

Chambers, supra, at 1131 n.102.

Dr. Theodore Sarbin, professor and Chairman of the Board of Studies in Psychology at the University of California at Santa Cruz, recently wrote: "For many years we have believed that there is a disease called schizophrenia. This belief is false. Schizophrenia, once a useful metaphor, is a myth." Sarbin, supra note 18 , at 18 . As Dr. Sarbin points out, using a definition taken from a widely used diagnostic manual: Schizophrenia "may" do this and it "sometimes" leads to that. It produces "characteristic" disturbances (unspecified) and "inappropriate" emotional responses (also unspecified). It is therefore not surprising that psychiatrists Id. have notoriously high rates of disagreement in their diagnoses of this illness.

This vagueness in the diagnostic terms of psychiatry is not due to a lack of research; there have been at least five thousand papers reporting on schizophrenia in the five decades since 1920. SCHEFF, supra note 3 , at 7 . Yet the results of this massive research output have been negligible. D. JACKSON, THE ETIOLOGY of SchizopHRENIA 3-4 (1960), cited in ScHEFF, supra, at 8. Not only have systematic studies failed to produce significant findings with respect to causation, but a number of theorists have expressed the belief that "the problem itself has not been formulated correctly." SCHeFF, supra, at 9.

92. Linn Interview, supra note 11. See notes 67-71 supra and accompanying text. 
clearly. Thus, a person who does not share the clinician's viewpoint or orientation in a situation may be seen as "disoriented." who does not perceive reality in the same way as his or her therapist may be characterized as "out of context." 04 A person who behaves in ways that are inexplicable to the clinician may be diagnosed as engaging in "bizarre" behavior. ${ }^{95}$

Lawyers who represent clients at commitinent hearings or release proceedings need to develop a skeptical attitude toward psychiatric labelling. ${ }^{96}$ By placing the diagnosing physicians on the witness stand and subjecting thein to searching cross-examination, it will often be

93. Telephone interview with Marge Madonn, Deputy Public Defender, Contra Costa County, in Martinez, California, March 22, 1974 [hereinafter cited as Madonn Interview]; telephone interview with Lce Coleman, M.D., Psychiatrist and Child Psychiatrist, in Berkeley, California, March 22, 1974 [hereinafter cited as Coleman Interview]. For a discussion of the meaningless, complex, or simply foolish orientation questions asked during psychiatric examinations, which often form the basis for a diagnosis of "disoriented," see SCHEFF, supra note 3, at 145-46.

94. Madonn Interview, supra note 94; Coleman Interview, supra note 94. One commentator notes that psychiatric diagnosis itself takes place out of context, so that behavior which is perfectly meaningful in the context of the patient-inmate's life often appears "symptomatically out-of-context." SCHEFF, supra note 3, at 174-75.

95. Madonn Interview, supra note 94; Coleman Interview, supra note 94. See Napa State Hospital, Behavior Rating Scale (1973) (on file with the Center for the Study of Legal Authority and Mental Patient Status, P.O. Box 822, Berkeley, California 94701).

96. The attorney representing a person accused of schizophrenia, for example, should consider some alternative formulations of "the problem" in probing for the details of a diagnosis calling for the involuntary mental institutionalization of a client. The British psychiatrist R.D. Laing, in discussing the difficulty of arriving at an objective defimition of schizophrenia, has concluded: "[s]chizophrenia is a label affixed by some people to others in situations where an interpersonal disjunction of a particular kind is occurring. This is the nearest one can get at the moment to something like an 'objective' statement, so called." R. Laing, The Politics of Experience 43 (1967). Dr. Laing discusses an alternative approach, which may be of use in defending a client accused of suffering froin sehizophrenia. Id. at 72-73.

Another psychiatrist, Dr. David Cooper, offers a tentative definition of schizophrenia as a particular kind of "micro-social crisis situation." D. Cooper, PSYchutRY AND ANTr-PSYCHIATRY 2 (1967).

A personal disjunction, or a micro-social crisis situation, of the type under discussion means essentially a disagreement among parties as to what is really happening among them in the situation in question. In such a situation the label "schizophrenic" serves to invalidate the perceptions and preferences of one of the disputing parties. In an action for the involuntary institutionalization of a woman, for example, lawyers should try to discover what is really happening. Has the woman been badly neglecting the children, or is there a husband or some other relative involved who wants to use the coinmitment process as a means to obtaining control over the woman and her children? Has the client's behavior been "bizarre" or "dangerous," or has it simply been a natural human response to pressures exerted by the husband and existing in the marriage? Is a young woman "acting out," or is she attcmpting to exercise freedom of choice in the question of domicile or sexual relations? These are the kinds of conflict situations which may be concealed by the pseudo-scientific terminology of a psychiatric diagnosis. 
possible to expose the nature of the underlying problem in a manner that makes clear the mappropriateness of attempting a medical solution. Likewise, the introduction of alternative psychiatric testimony can prove a useful aid in probing the conflicts involved, as well as illustrating the frequently normative nature of the opposing psychiatric testimony.

\section{IV}

\section{Sex-Based Discrimination in Psychiatry: The Legal Dilemma AND SOME PROPOSALS FOR REFORM}

The foregoing review of the available evidence suggests the existence of a widespread and pervasive pattern of sex-based discrimination in civil commitment, treatment, and release. Comprehensive research into the institutionalization of wounen in all types of inental health facilities is vitally needed. Until such research is coinpleted, ultimate legal remedies remain speculative. If research reveals that sex-based discrimination is, as it appears, an inherent or integral part of the civil commitment process, or if psychiatric standards indeed are so open-ended that clinicians' personal bias cannot be excluded, then the entire system is subject to attack on constitutional grounds.

The civil commitment system meets preliminary requirements for review under the fourteenth amendment. ${ }^{97}$ Although civil commitment statutes are not discriminatory on their face, discrimination in application also constitutes a violation of the fourteenth amendment. ${ }^{98}$ State action is present since courts enforce and legislatures finance the machinery of commitunent.99

97. The Equal Rights Amendmeut (H.R.J. Res. 208, 92d Cong., 1st Sess. (1971); S.J. Res. 8, 92d Cong., 1st Sess. (1971)), if ratified, would provide another basis for constitutional attack. Professor Thomas I. Emerson has argued that the Equal Rights Amendment should be an "absolute" constitutional mandate, and not merely provide a reasonableness or even strict scrutiny approach to sex-based classifications. Brown, Emerson, Falk, \& Freedman, The Equal Rights Amendment: A Constitutional Basis for Equal Rights for Women, 80 YALE L.J. 871, $891-893$ (1971). Should the Court adopt this approach, all legislation which discriminates either on its face or in its application would be invalidated. The Senate and House Reports on the Amendment, which indicate legislative intent, suggest a more tentative approach, and use terms like "reasonable classifications" and "rules of reason." HOUSE COMM. ON THE JUDICIARY, H.R. Rep. No. 92-359, 92d Cong., 2d Sess. 839 (1971); Senate Comm. on the Judiciary, EQUal RIGHTS For MEN AND Women, S. REp. No. 92-689, 92d Cong., 2d Sess. 12 (1972).

At this point, however, the nature and extent of the protection that the amendment would provide is necessarily speculative.

98. Yick Wo v. Hopkins, 118 U.S. 356, 373-74 (1886).

99. The state also licenses psychiatrists, e.g., CAL. Bus. \& Prof. CoDe $\$ 2190$ et seq. (West Supp. 1973); psychologists, e.g., CAL. Bus. \& Prof. Code $\S 2900$ et seq. (West Supp. 1973); and mental health facilities, e.g., CAL. HeAlth \& SAFETY CODE $§$ 
Although distinctions based on sex historically were not considered violations of the equal protection clause, ${ }^{100}$ they have recently been reviewed under a "reasonableness" test, ${ }^{101}$ and it is possible that sex may be held to be a suspeot classification requiring strict judicial scrutiny. ${ }^{102}$

Characterization by sex is qualitatively similar to other characterizations, like those based on race and ancestry, previously considered suspect by the courts. ${ }^{103}$ It is urged that sex be so considered.

But even if courts refuse to recognize that sex is a suspect basis for classification, there is an independent basis for the application of strict scrutiny to mental health law, since fundamental rights are at stake. Liberty has long been recognized as a fundamental interest. ${ }^{104}$ When women are subjected to civil commitment on the basis of sexually discriminatory standards, a fundamental right is abridged and the state must demonstrate a compelling interest in order for such practices to meet constitutional requirements. ${ }^{105}$

Other fundamental rights appear to be involved as well. Women deprived of liberty are also deprived of the right to be the kind of person they might choose to be. The right to develop one's own mind and personality in ways of one's own choosing has been upheld in a

1310 et seq. (West Supp. 1973). Mental health facilities receive considerable economic support from both the state and federal governments. California, for example, spent $\$ 1.5$ billion on mental health services during the last ten years. Exchunoe (publication of the California Department of Mental Hygiene), February 1973, Vol. 1, No. 3, at 40. In 1971, federal involvement in California mental health services amounted to $\$ 17$ million. $I d$.

100. E.g., Muller v. Oregon, 208 U.S. 412, 421-23 (1908); Bradwell v. Illinois, 83 U.S. (16 Wall.) 130, 139-41 (1872) (Bradley, J., concurring).

101. E.g., LaFleur v. Cleveland Bd. of Educ., 465 F.2d 1184 (6th Cir. 1972), aff'd 42 U.S.L.W. 4186 (U.S. Jan. 21, 1974); Reed v. Reed, 404 U.S. 71 (1971). For a comprehensive discussion of the new use of the reasonableness test in sex classifications, see Note, LaFleur v. Cleveland Board of Education: An Unarticulated Application of the New Approach to Equal Protection, 35 U. PirT. L. Rev. 141 (1973).

102. See Frontiero v. Richardson, 411 U.S. 677, 688 (1973). But cf. Kahn v. Shevin, 42 U.S.L.W. 4591 (U.S. April 24, 1974) (Douglas, J. distinguishes Frontiero).

103. Sail'er Inn, Inc. v. Kirby, 5 Cal. 3d 1, 18, 485 P.2d 529, 540, 95 Cal. Rptr. 329,340 (1971).

An additional reason for strict scrutiny is that disadvantaged groups "are not always assured of a full and fair hearing through the ordinary political processes." Hobson v. Hansen, 269 F. Supp. 501, 507-08 (D.D.C. 1967), modified sub. nom. Smuck v. Hobson, 408 F.2d 175 (D.C. Cir. 1969). Like blacks, women are markedly underrepresented in all branches of government, as well as in other nongovernmental institutions such as business management, and the administration of mental institutions. See notes 37 and 53 supra and accompanying text. Denied access to the normal channels of social change, women accused of mental illness are in need of the special protection of the courts.

104. West Virginia State Bd. of Educ. v. Barnette, 319 U.S. 624, 638 (1943).

105. Dunn v. Blumstein, 405 U.S. 330, 338-39 (1972). 
variety of contexts, often under the aegis of privacy. ${ }^{106}$

The privacy cases are peculiarly analogous to the position of women vis a vis commitment laws because they consider the extent to which government at any level can impose identity on a class of people by limiting the scope of permissible behavior or self-expression. Women are demied precisely these rights under many commitment laws and practices; their personalities are circumscribed and limited by pseudomedical definitions of female health which require them to adhere to their "anatomical destiny" on penalty of being found insane. ${ }^{107}$

A fundamental right, whether privacy or individual liberty, cannot be abridge without a showing of a compelling state interest, ${ }^{108}$ and certainly not on the basis of an assumption unsupported by convincing evidence. ${ }^{109}$ By incorporating prevailing, but unsupported, psychiatric attitudes about women into civil commitment, states have adopted a theory of the female role and elevated it to the status of law. Such attitudes form an insufficient basis for a finding of compelling state interest. To the extent, therefore, that sex-based discrimination is found to be a'significant part of the civil commitment system, civil commitment practices should be declared unconstitutional under the fourteenth amendinent.

Until a thoroughgoing overhaul of the mental commitment proc-

106. The government cannot require that children attend public schools, Pierce v. Society of Sisters, 268 U.S. 510 (1925), nor forbid the teaching of foreign languages in private schools, Meyer v. Nebraska, 262 U.S. 390 (1923). Private possession of obscene material cannot be forbidden, Stanley v. Georgia, 394 U.S. 557 (1969), nor can the use of contraceptives by adults, Eisenstadt v. Baird, 405 U.S. 438 (1972); Griswold v. Connecticut, 381 U.S. 479 (1965). And, a woman's right to obtain an abortion, while not absolute, cannot be unduly encumbered. Roe v. Wade, 410 U.S. 113 (1973); Doe v. Bolton, 410 U.S. 179 (1973).

One judge has commented, "Our institutions do not rely on submerging individual personality in order to create an 'idealized' citizen. . . . [Individuals] must be given every feasible opportunity to grow ... to develop their own individualities and to initiate and thrive on creative thought." Bishop v. Colaw, 450 F.2d 1069, 1078 (8th Cir. 1971) (Lay, J., concurring).

107. See notes 11-22 supra and accompanying text. See generally notes 37-85 supra and accompanying text.

108. Roe v. Wade, 410 U.S. 113, 155 (1973); Kramer v. Umion Free School Dist., 395 U.S. 621,627 (1969); Shapiro v. Thompson, 394 U.S. 618,634 (1969).

109. Stanley v. Georgia, 394 U.S. 557, 566-67 (1969). Cf. Skinner v. Oklahoma, 316 U.S. 535, 546 (1942) (Jackson, J., concurring).

In Stanley v. Georgia, for example, the Supreme Court rejected an argument that obscene literature might lead to sexual deviation or crime. In the absence of an empirical demonstration of the validity of such an assunption, the state could not regulate what was essentially a private activity. 394 U.S. at 566-67. In the recent abortion case of Roe $v$. Wade the Supreme Court similarly took notice of the lack of agreement about the moment when human life begins. The Court concluded that since the moment when human life begins could not be accurately determined, the state had a compelling interest in the life of the foetus only after viability. Roe v. Wade, 410 U.S. $113,160-64$ (1973). 
ess is carried out, ${ }^{110}$ strict scrutiny of each individual case involving the commitment, treatment, and release of women is necessary. Attorneys and judges mvolved in such cases should view the situation with a specific understanding of the tremendous inherent possibilities of sex-based discrimination. In doing so, attorneys will find it helpful to bear in mind the major questions suggested by this article: (1) Do the facts indicate the presence of sex-based discrimination:

A. At the admissions level. Is a husband trying to get custody of the children? Are parents punishing or trying to conceal a daughter's promiscuity? Is the woman being pumished for attempting to explore a new or unconventional mode of living?

B. At the level of treatment. Is the woman being "treated" for refusing to perform menial domestic tasks? For engag$\mathrm{mg}$ in aggressive sexual behavior? For displays of temper or self-assertion that would be tolerated in a man?

C. At the release level. Is the fernale patient-inmate being held for refusing to adopt a sex-stereotyped role? Because she has no job? Because of the therapist's "protectiveness" or feelings of "sympathy"?

110. One possibility would be the establishment of an expanded system of voluntary services. Some such services might be patterned after the highly successful suicide prevention and crisis intervention centers that have been established in a number of communities. These services, which need not and should not be patterned on the medical model, can provide valuable sources of assistance for what are essentially problems in living.

The development of community-based "human services networks" as alternatives to both the state mental imstitution and the community mental health center is a relatively recent phenomenon. See Curtis, Community Services Networks: New Roles for Mental Health Workers, 3 Psxchintric AnNals 7 (1973). Negotiations toward the formation of such a network in the City of Berkeley, California, indicated the potential for coordination of a wide range of voluntary services oriented toward an essentially nonmedical model. See Community Coordinated Care Program (1973) (unpublished paper on file with the Center for the Study of Legal Authority and Mental Patient Status, P.O. Box 822, Berkeley, California 94701). There is a national trend away from the use of isolated state mental institutions toward the establishment of communitybased mental health centers. See, e.g., Chambers, Alternatives to Civil Commitment of the Mentally Ill: Practical Guides and Constitutional Imperatives, 70 MicH. L. Rev. 1107 (1972). Such a change in the locus of services does not, however, necessarily revise the essentially clinical, or medical, orientation of the personnel involved, in the - absence of some commitment to a nonmedical model. See Curtis, supra. The Mctropolitan Center for Problems in Living is an interesting institutional structure based on Szaszian conceptualization. See Capell, The Metropolitan Center for Problems in Living: An Experiment in Autonomy, 24 AMER. Psychologist 171 (1969). The suggestion for an expanded system of voluntary services is premised on the assumption that such experimental "human services networks" conceive of the problems involved as nonmedical problems, or problems in living, and of services to be provided as purely voluntary. 
(2) Does the testimony of the opposing psychiatrist give evidence of his or her personal bias against women or reliance on discriminatory theories? Does he or she believe, for example, that women should be less aggressive, are weaker, are better suited to domestic activities, or are more unstable than men because of inherent hormonal factors?

Knowledgeable attorneys, aided by expert witnesses, can explore these and other areas as possible sources of invidious treatment. And, while elimination of sex-based discrimination in psychiatry is the work of at least a generation, in the ineantime an active legal defense based upon an awareness of these perspectives should be available to every woinan accused of mental illness. 